\title{
Identification of surface-basement layer distribution of Wangi-Wangi Island based on HVSR method of microtremor data
}

\author{
Rani Chahyani ${ }^{1, *)}$, Abdul Manan ${ }^{2}$, Cindy Puspitafury ${ }^{3}$ and Kasmawati ${ }^{3}$ \\ ${ }^{1}$ Program Studi Tadris Fisika, Fakultas Tarbiyah dan Ilmu Keguruan, IAIN Kendari \\ ${ }^{2} J u r u s a n$ Teknik Geofisika, Fakultas Ilmu dan Teknologi Kebumian, Universitas Halu Oleo \\ ${ }^{3}$ Badan Penelitian dan Pengembangan (BALITBANG) Provinsi Sulawesi Tenggara \\ *) rani.chahyani@gmail.com
}

Received 15 June 2020, Revised 19 August 2020, Published 30 September 2020

\begin{abstract}
To find out the distribution of the surface-basement layer of Wangi-Wangi Island, it can be done by calculating the surface layer thickness of each measurement point using microtremor data. The surface layer thickness $(h)$ also indicates the position of the basement to the surface. The microtremor recording data used in this study were 47 data. Furthermore, the data were processed using the HVSR method to obtained the soil predominant frequencies which together with the $V_{\mathrm{s} 30}$ values were used to calculated the $h$ values. The results showed that the thickness of the surface layer or sediment layer of Wangi-Wangi Island was in the range of 5.7339 to 241.2557 meters. Based on its distribution, the areas with a thick surface layer are in the areas of Sombu, North Wandoka, Wandoka, South Wandoka, Pada Raya Makmur and Wanci. In the case of a disaster, these areas are thought to have the most potential to experience damage if an earthquake shakes.
\end{abstract}

Keyword : Microtremor, HVSR, Surface Layer Thickness, Basement, Earthquake

\section{Introduction}

The Wangi-Wangi Island is one of the large islands in the rows of islands that make up the Wakatobi archipelago. Apart from Wangi-Wangi Island, the other major islands are Kaledupa Island, Tomia Island and Binongko Island. Wangi-Wangi Island is a group of coral islands, and is an island with a sloping topography. On the island of WangiWangi, there are many karst caves that can be seen physically in many places scattered on the island's surface. Geologically, the mainland rocks of Wangi-Wangi Island are limestone which is made from coral limestone and some of it is suppressed by Ambeua formation which is made from globigerina and limestone marl.

In the province of Southeast Sulawesi, there are many active faults, including the Lawanopo fault, Kolaka fault, Konaweha fault, Tolo fault, Sangi-sangi fault, Labengke 
fault, Buton fault, Kendari fault and Matano fault. As a result of these faults, Southeast Sulawesi Province is prone to earthquakes. Earthquakes occur because of fault motion activity on a scale that allows large bursts or releases of energy. Based on data from the BMKG Stasiun Geofisika Kendari in 2020, between 2007 and 2019 there were 6,882 earthquakes in the Southeast Sulawesi province.

Earthquake waves leave traces in the rock layers or soil layers that they pass through, so they can be quantified in a certain way. To identify it, it can be done by analyzing the microtremor data obtained by cutting the ground vibration data frequency at the microtremor frequency. Meanwhile, ground vibration data is obtained through direct measurements in the field. Ground vibrations originate from human activities, traffic, industry, and also from natural activities such as ocean currents, wind-building interactions as well as long-period ocean waves (Bard et al., 2004; Petermans et al., 2006). In Kanai (1983), it is stated that microtremor is a small continuous vibration of the ground which comes from natural activities and human activities.

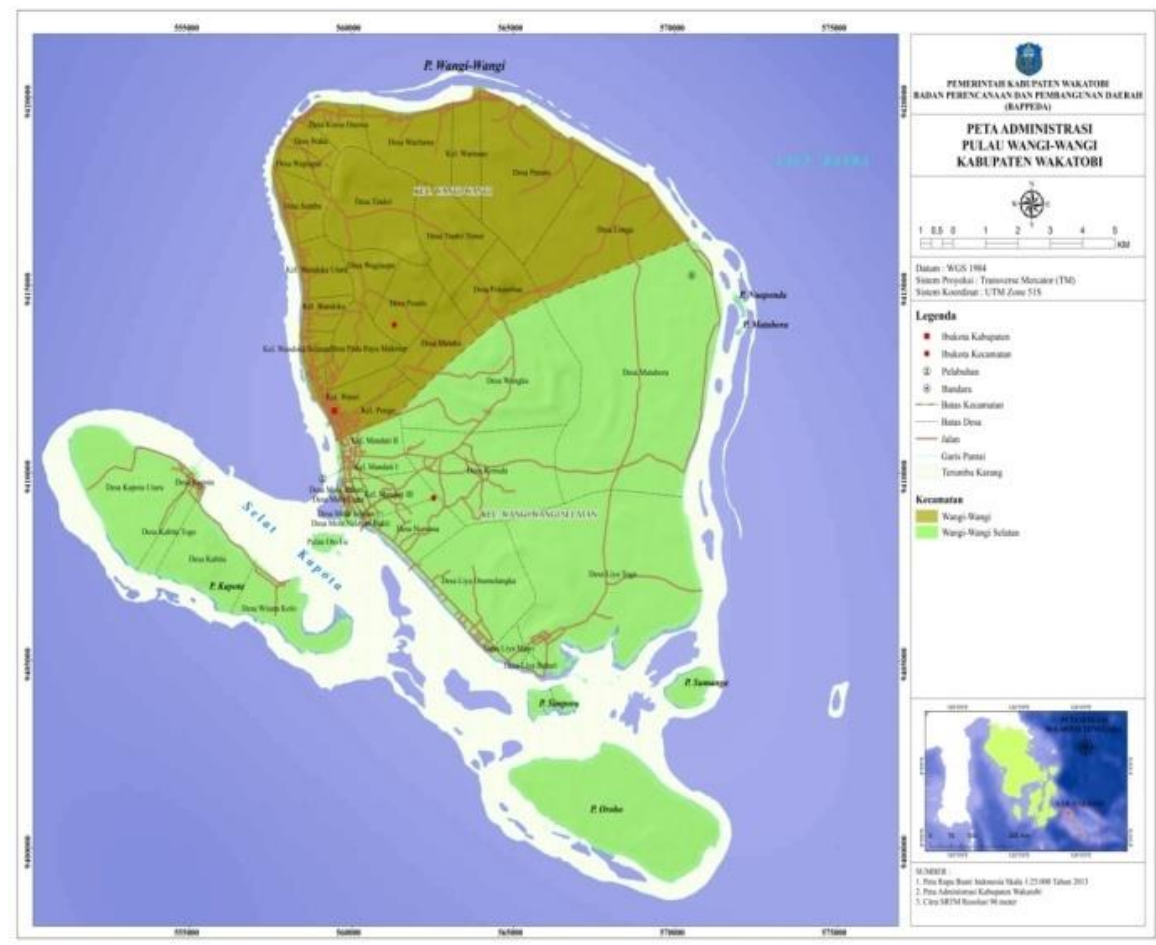

Figure 1. Map of Wangi-Wangi Island administration

Earthquakes are natural events that are sure to happen. Therefore, knowledge of the parameters that cause the level of damage when an earthquake occurs is needed, especially as an illustration to support mitigation efforts undertaken by local governments. One of the parameters that affect the level of damage to the surface in the event of an earthquake shock is the thickness of the surface layer or the depth of the basement of an area. By knowing the distribution of the surface-basement layer of Wangi-Wangi Island, it can provide a qualitative description of the potential damage.

Microtremor data can be analyzed using the Horizontal to Vertical Ratio (HVSR) method developed by Nakamura (2000) and Nakamura (2008) to produce soil predominant frequency data and amplification factors. These two parameters are then 
used to calculate the thickness of the surface layer or the depth of the basement of the surface on Wangi-Wangi Island.

\section{Research Method}

This research is located in Wangi-Wangi Island which is at $5^{\circ} 15^{\prime} 6,41^{\prime \prime}-5^{\circ} 22^{\prime} 39,32^{\prime \prime}$ South Latitude dan $123^{\circ} 31^{\prime} 15,10^{\prime \prime}-123^{\circ} 37^{\prime} 59,48^{\prime \prime}$ East Longitude. Administratively, Wangi-Wangi Island is in the Wakatobi Regency area, and is divided into 2 subdistricts, namely Wangi-Wangi District and South Wangi-Wangi District. The research location can be seen in Figure 1. Ground vibration data collection on Wangi-Wangi Island was carried out from June 28 to July 03, 2020.

The data used is microtremor data obtained from cutting ground vibration data. Ground vibration data were obtained from direct measurements in the field using a set of TDS-303 portable seismographs. The distribution of measurement points can be seen in Figure 2. The number of measurement points is 47 divided into 7 lines, the distance between lines is $2 \mathrm{~km}$ and the average distance between measurement points is $1.9 \mathrm{~km}$. Ground vibration data were recorded in the field for 29.25 to 48.16 minutes following the guidance of the SESAME European Research Project (Bard et al., 2004).

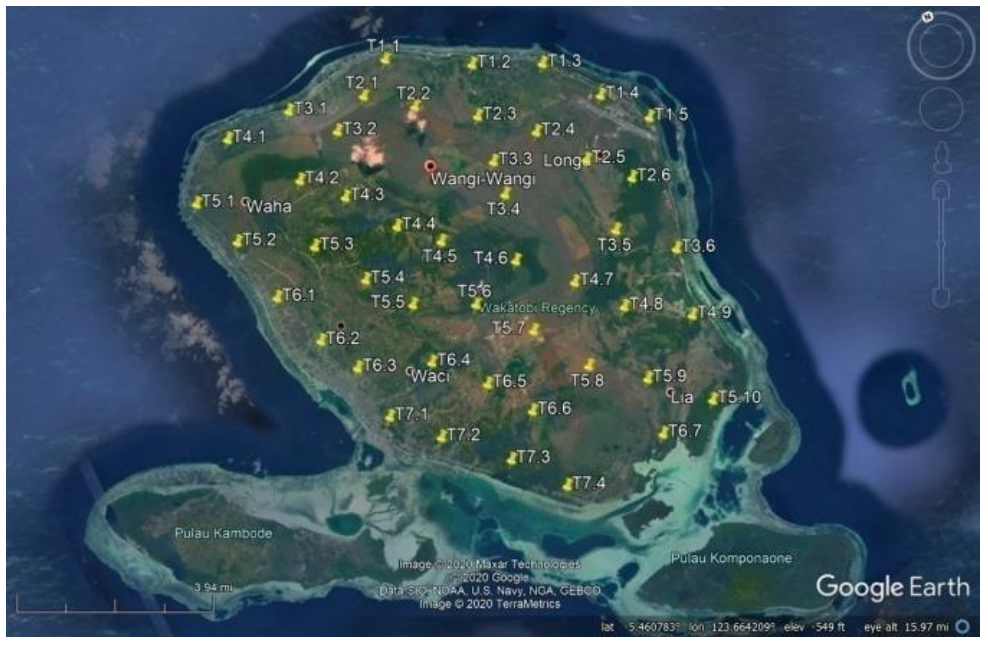

Figure 2. Distribution of measurement points on Wangi-Wangi Island

The recorded ground vibration data is stored in the Seismograph Digitizer TDS-303 in .trc (trace) format. To be able to be analyzed further, the data format must first be converted into MSD (Minisheed) format using the DataPro.exe software. Furthermore, ground vibration data is cut at a frequency of 0.5 to $25 \mathrm{~Hz}$ (Haerudin et al., 2019) to obtain microtremor data using the Band Pass Filter found in the Geopsy 3.2.2 software.

The microtremor data that has been obtained are then processed by the Horizontal to Vertical Spectral Ratio (HVSR) method to obtain the predominant soil frequency $\left(f_{\mathrm{o}}\right)$ and the amplification factor $\left(A_{0}\right)$. These two parameters will be used in calculating the thickness of the surface layer or the basement depth of the surface $(h)$ of Wangi-Wangi Island. Nakamura (2000) and Nakamura (2008) have presented an equation for calculating the value of $h$ assuming the surface layer density and basement density are the same: 


$$
h=\frac{V_{s}}{4 f_{0}}
$$

where $V_{S}$ is the velocity of the shear wave (S) on the surface. In this study, the $V_{s}$ value used was $V_{s 30}$ which was obtained from the United States Geological Survey (USGS) website at www.usgs.gov. Furthermore, a 3D model is created using RockWork 17 software to determine the distribution of the surface-basement layer or the position of the basement to the surface.

This research generally follows the flow chart in Figure 3. The figure shows the steps taken until the $h$ value is obtained. Furthermore, these results will lead to conclusions in the Conclusions section.

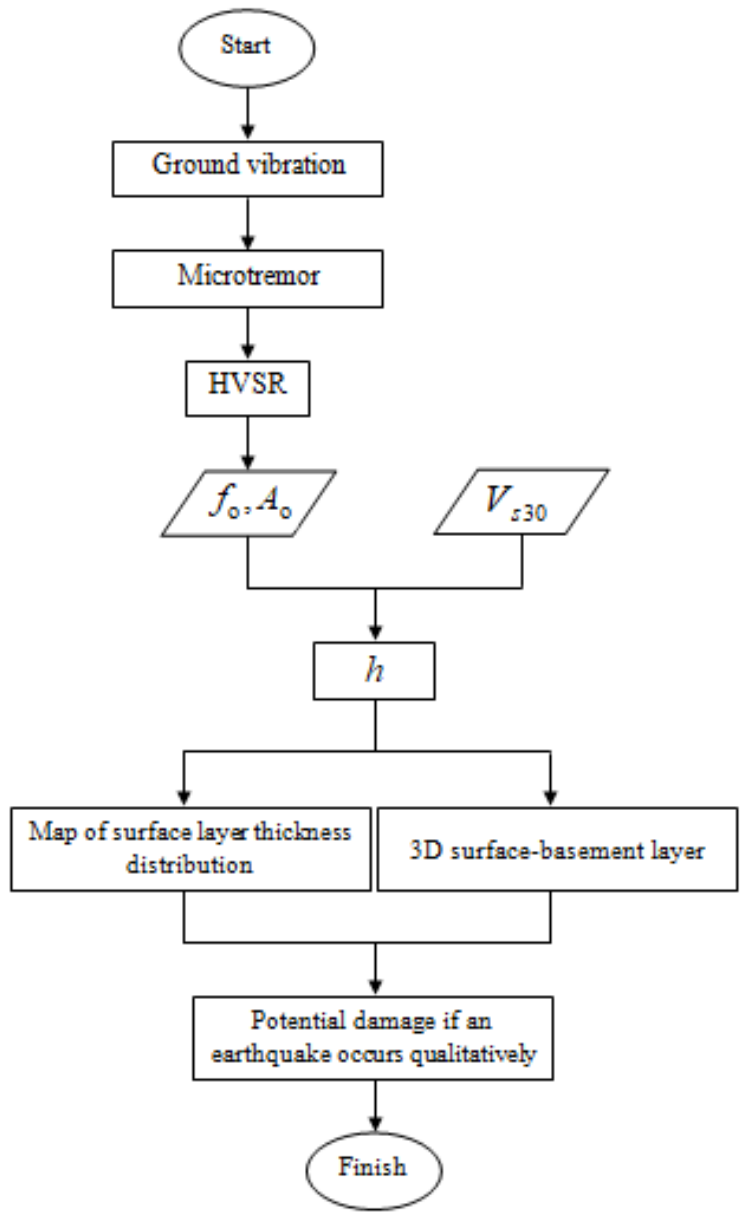

Figure 3. Research flow chart

\section{Result}

The ground vibration signal stored in the TDS-303 portable Seismograph Digitizer for measurement point T4.9 can be seen in Figure 4. The figure shows the signal in 3 components, namely 1 vertical component (station $\mathrm{Z}$ ) and 2 horizontal components (EW station and NS station). The data is already in .trc format, so that it can be further processed using Geopsy 3.2.2 software. Microtremor data is obtained after cutting the ground vibration data frequency at a frequency of 0.5 to $25 \mathrm{~Hz}$. To get the soil predominant frequency $\left(f_{o}\right)$ and the amplification factor $\left(A_{o}\right)$ of each measurement point, 
the HVSR method was used. The HVSR spectrum for the measurement point T4.9 can be seen in Figure 5, and the data $f_{o}$ and $A_{o}$ for all measurement points can be seen in Figure 6.

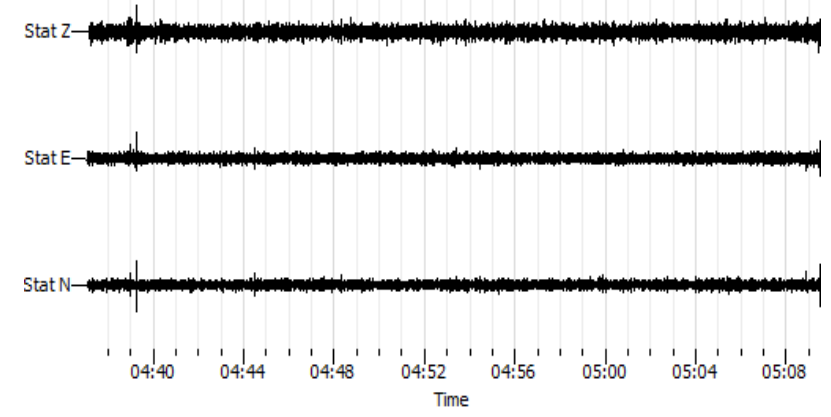

Figure 4. Microtremor signal at measurement point T4.9

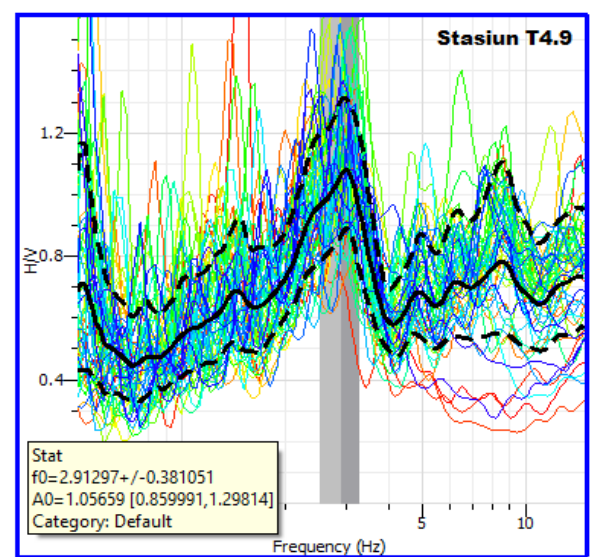

Figure 5. HVSR spectrum of measurement point T4.9

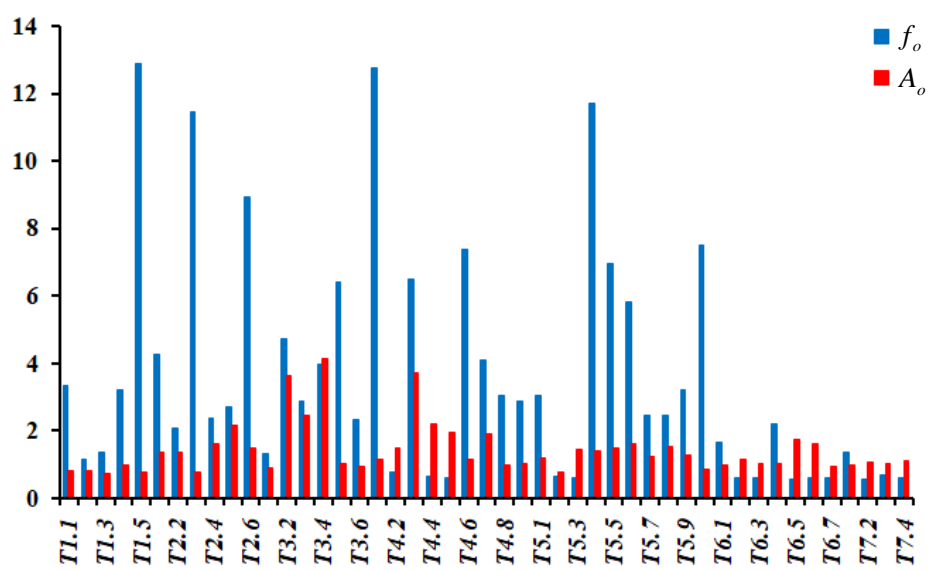

Figure 6. Data of the soil predominant frequency $\left(f_{o}\right)$ and amplification factor $\left(A_{o}\right)$ of Pulau Wangi-Wangi for all measurement points

Based on Figure 6, the predominant soil frequency $\left(f_{o}\right)$ of Wangi-Wangi Island is in the range 0.601932 to $12.8917 \mathrm{~Hz}$, and the amplification factor $\left(A_{o}\right)$ is in the range 0.757009 to 4.17365 . The $V_{\mathrm{s}}$ data uses $V_{\mathrm{s} 30}$ which is obtained from the USGS website, www.usgs.gov. $V_{\mathrm{s} 30}$ is the shear wave velocity from the ground to a depth of 30 meters, and is widely used in geophysical engineering to determine the characteristics of 
subsurface structures (Roser and Gosar, 2010). Data on $V_{\mathrm{s} 30}$ Wangi-Wangi Island based on the distribution of measurement points in Figure 2 can be seen in Figure 7.

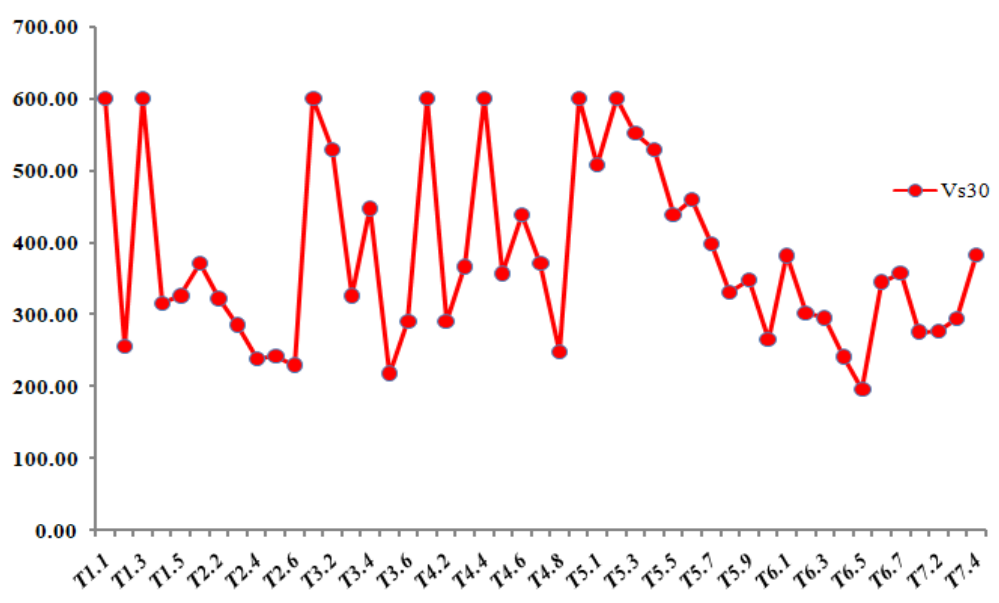

Figure 7. $V_{s 30}$ data for Wangi-Wangi Island

The data in Figures 6 and 7 are then used to calculate the thickness of the surface layer of Wangi-Wangi Island using Nakamura's formula (Nakamura, 2000; Nakamura, 2008) in Eq. (1). The surface layer thickness obtained in this study is an estimated value because it is based on the assumption that the surface layer density and basement are the same. The surface layer thickness also indicates the depth of the basement. Based on Figure 8, the thickness of the surface layer of Wangi-Wangi Island ( $h$ in meters) is divided into 7 data classes, namely data class 5,7339-39,3799, class $39,3799-73,0258$, class $73,0258-106,6718$, class $106,6718-140,3178$, class $140,3178-173,9637$, class $173,9637-207,6097$, and class $207,6097-241,2557$. The dominant data class is the class $5,7339-39,3799$ or the data class with the least thickness. So the range of surface layer thickness of Wangi-Wangi Island is in the range of 5,7339 to 241,2557 meters.

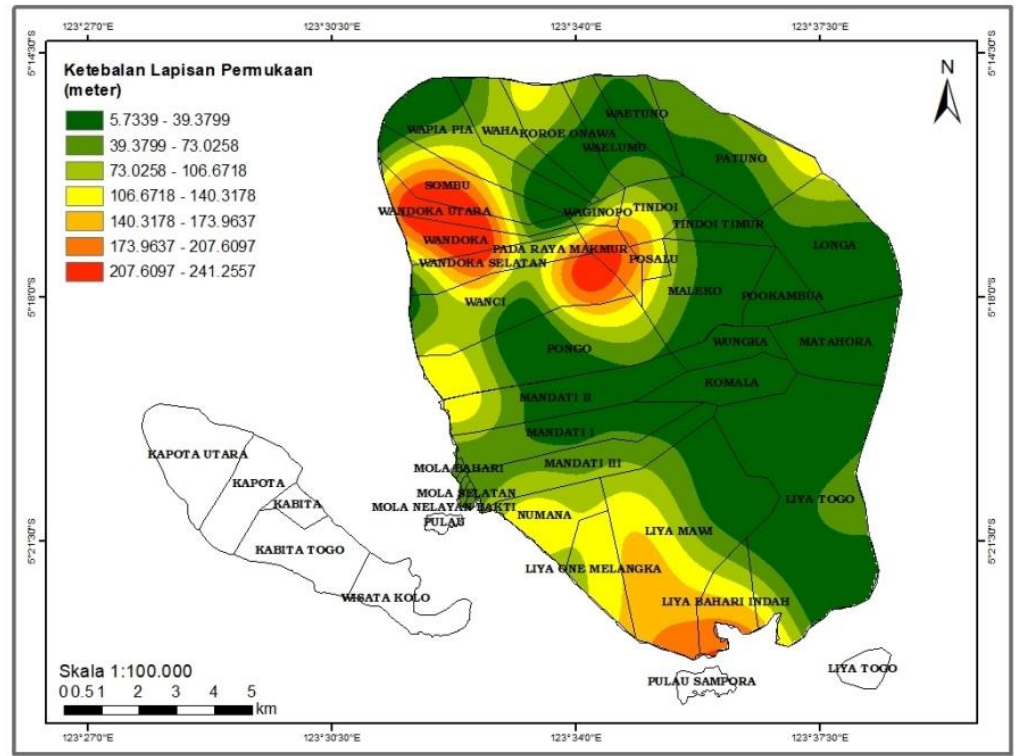

Figure 8. Map of surface layer thickness distribution $(h)$ of Wangi-Wangi Island 
Based on Figure 8, Wangi-Wangi Island has the thickest surface layer in the areas of Sombu, North Wandoka, Wandoka, South Wandoka, Pada Raya Makmur and Wanci. The 3D distribution of the surface-basement layer of Wangi-Wangi Island is shown in Figure 9. Qualitatively, these areas indicate the greatest potential for damage if an earthquake shakes. This is because in these areas there is a greater contrast between the surface layer and the basement compared to other areas. A large $h$ value causes the earthquake waves to be trapped for longer in the surface layer, resulting in a large amplification which affects the magnitude of the earthquake shock. In the Nakamura's approach (Nakamura, 2000; Nakamura, 2008), the surface layer is associated with a sedimentary layer. When an earthquake occurs, the areas with the most potential for damage are areas with thick soft sediment that are above the hard basement (Wulandari et al., 2016).

Symptoms of amplification in an area occur due to earthquake waves trapped in a sediment layer. In Arifin et al. (2014) it is stated that earthquake waves will experience amplification if they propagate from one layer to another which is softer. The more contrast the layer, the greater the amplification experienced by the wave.
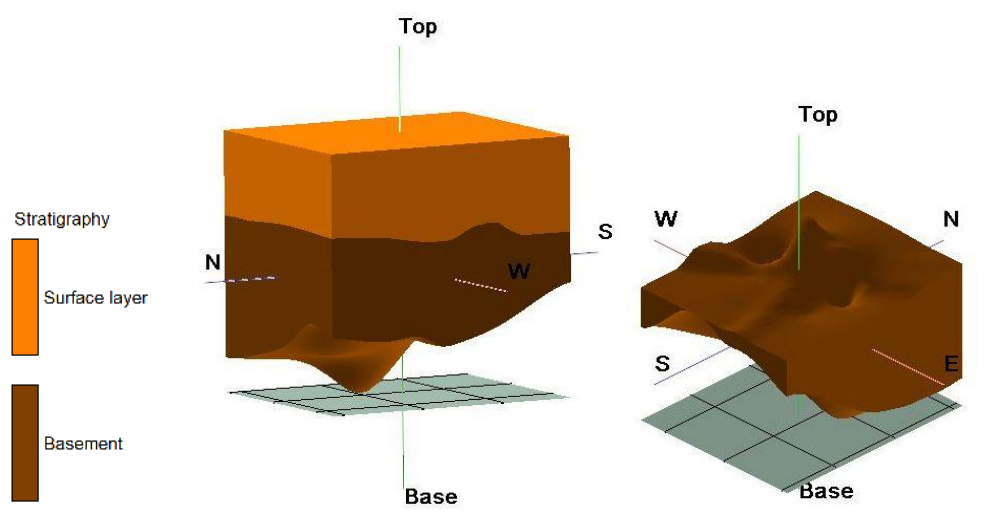

Figure 9. (a). Surface-basement layer and (b). Basement topography

\section{Conclusion}

From the results of this study, it can be seen that Wangi-Wangi Island has a surface layer thickness between 5,7339 to 241,2557 meters. Areas with the thickest surface layer are in the areas of Sombu, North Wandoka, Wandoka, South Wandoka, Pada Raya Makmur and Wanci. These areas are the areas that are suspected to have the greatest potential for damage if an earthquake shakes.

To better determine the potential damage on Wangi-Wangi Island in the event of an earthquake shock, further analysis of the microtremor data is required. This further analysis can be done by calculating the parameters of the Seismic Vulnerability Index $\left(K_{g}\right)$, Peak Ground Acceleration (PGA) and Ground Shear Strain (GSS).

\section{Acknowledgements}

We hereby express our gratitude to Badan Penelitian dan Pengembangan (BALITBANG) Provinsi Sulawesi Tenggara for providing funding for microtremor 
research on Wangi-Wangi Island through SK Gubernur Sulawesi Tenggara Nomor 7 Tahun 2020 dated 5 February 2020. In addition, we also express our gratitude thanks to BMKG Stasiun Geofisika Kendari for permission and assistance in using its TDS-303 Seismograph for data collection in the field.

\section{References}

Arifin, S.S., Mulyatno, B.S., Marjiyono dan Setianegara, R. (2014). Penentuan Zona Rawan Guncangan Bencana Gempa Bumi Berdasarkan Analisis Nilai Amplifikasi HVSR Mikrotremor dan Analisis Periode Dominan Daerah Liwa dan Sekitarnya. JGE (Jurnal Geofisika Eksplorasi) 2(1) : 30-40.

Bard, P.Y., Atakan, K., Anastasiadis, A. and Azzara, R.M. (2004). Guidelines for the implementation of the $\mathrm{H} / \mathrm{V}$ spectral ratio technique on ambient vibrations: measurements, processing and interpretation. SESAME European Research Project, European Commission - Research General Directorate. Available at:

Haerudin, N., Alami, F. dan Rustadi. (2019). Mikroseismik, mikrotremor dan microearthquake dalam ilmu kebumian. Bandar Lampung : Pusaka Media.

http://sesame.geopsy.org/Papers/HV_User_Guidelines.pdf (Accessed: 11 January 2021)

https://www.sdr.co.jp/eng_page/papers/14wcee/14wcee_hv.pdf (Accessed: 20 December 2020)

https://www.sdr.co.jp/papers/n_tech_and_application.pdf (Accessed: 22 December 2020)

Kanai K. (1983) Engineering seismology. Tokyo : University of Tokyo.

Nakamura Y. (2008). On the H/V spectrum. The $14^{\text {th }}$ World Conference on Earthquake Engineering, 12-17 October 2008, Beijing, China. Available at:

Nakamura, Y. (2000). Clear identification of fundamental idea of Nakamura's technique and its applications. The $12^{\text {th }}$ World Conferences on Earthquake Engineering (12WCEE), Auckland 30 January - 4 February 2000. Available at:

Petermans, T., Devleeschouwer, X., Pouriel, F. and Rosset, P. (2006). Mapping the local seismic hazard in urban area of Brussel Belgium. IAEG paper : 1-11.

Roser, J. and Gosar, A. (2010). Determination of Vs30 for Seismic Ground Classifications in the Ljubljana Area, Slovenia. Acta Geotechnica Slovenia $7(1): 61-76$.

Wulandari, A., Suharno, S., Rustadi, R. dan Robiana, R. (2016). Pemetaan Mikrozonasi Daerah Rawan Gempabumi Menggunakan Metode HVSR Daerah Painan, Sumatera Barat. JGE (Jurnal Geofisika Eksplorasi) 4(1) : 31-45. 